\title{
Communicating progress on meeting the United Nations Global Compact goals: An analysis of the South African experience
}

\section{Authors: \\ Prof Daniel Malan' Prof. Marius Ungerer ${ }^{1}$ \\ Affiliation: \\ ${ }^{1}$ University of \\ Stellenbosch Business \\ School}

\section{Correspondence to:}

Prof Daniel Malan,

University of Stellenbosch

Business School,

Carl Cronjé Drive,

Bellville 7530,

Cape Town,

South Africa

Tel:

+27829020269

E-mail:

daniel.malan@usb.ac.za marius.ungerer@usb.ac.za

DOI:

10.15249/11-2-158

\section{Keywords:}

Optimised Collective

Value; Corporate

Responsibility; United

Nations Global Compact

\section{Executive summary}

The purpose of business has been a consistent focus area in the field of corporate responsibility (CR). This article examines public disclosures on CR made by South African signatories to the United Nations Global Compact, with reference to recent contributions on the purpose of business.

Over time, the focus of $\mathrm{CR}$ has shifted from an internal corporate to a broader systemic perspective, reflecting the view that the responsibility of corporations cannot be addressed in isolation. In terms of purpose, Porter and Kramer present Creating Shared Value (CSV) as a way to reinvent capitalism. Donaldson and Walsh argue that what counts as value for a single firm is not the same as value for business in general, and propose a world where collective value is optimised.

Corporations have to confront global challenges with commitment and innovation. If they can do so successfully it will be in their own interest and also in the interest of the planet. It is frequently argued that - in addition - it will be the right thing to do from a moral perspective. The use of "in addition" is significant: it illustrates one of the key conceptual challenges to understanding the (perceived) tension between the business case and the moral case for corporate responsibility. "In addition" implies that the business case and the moral case are separate, but that, if they are aligned, there would be no tension. It is argued that the traditional resolution of this tension - enlightened self-interest - is both superficial and flawed.

It is proposed that more corporate support for CR based on a normative foundation should be encouraged, and that the concept of Optimised Collective Value is an appropriate way to achieve this. 
Using narrative analysis, the public disclosures of the 19 South Africa signatories to the UN Global Compact were assessed on the basis of their emphasis on either the business case or the moral case; on either the global or the local context; and either performance or conformance aspects of governance. Finally, a general assessment was made of whether the COPs were mainly a public relations exercise, mainly a compliance exercise, or whether a clear commitment to the principles of the UN Global Compact was demonstrated.

\section{Introduction}

The purpose of business has been a consistent focus area in the field of corporate social responsibility (CSR). Corporate social responsibility is defined by Carroll, Lipartito, Post, Werhane and Goodpaster (2012:7) as "the idea that the corporation exists in society and has rights and responsibilities as a member (or citizen) of that society". There is, however, a growing preference for the term "corporate responsibility" (CR), based loosely on the realisation that there is a need to move beyond an exclusive reference to social aspects (Smith \& Lenssen, 2009:6).

Furthermore, over time, the focus of $\mathrm{CR}$ has shifted from the corporate to the systemic perspective, reflecting the view that the responsibility of corporations cannot be addressed in isolation. Two contributions to this view are submitted in this article. Porter and Kramer (2011:3) describe how creating shared value (CSV) can "reinvent capitalism". Donaldson and Walsh (2015:202) propose "a world where collective value is optimised, where the dignity of every business participant is recognized and honored, where every act and decision in the world of business clears the Dignity Threshold". The dignity threshold is part of a range of carefully defined concepts, which will be discussed later, and refers to the minimum level of respect that should be accorded to business participants (Donaldson \& Walsh, 2015:188).

One of the reasons for this shift in focus is that corporations are increasingly confronted with challenges once thought to belong squarely in the domain of governments. Examples include climate change and increasing inequality between rich and poor, as well as political conflict and human rights abuses, especially in developing countries. In her response to the uncertainty and volatility caused by the outcome of the 2016 United States (US) presidential election, Erika Karp, CEO of Cornerstone Capital, confirms that some corporations embrace these challenges:

At Cornerstone we believe that the private sector will power progress in meeting the world's imperatives including addressing everything from climate change, water scarcity, income inequality, gender equity, and healthcare provision, to infrastructure building. ${ }^{1}$

Corporations have to confront these challenges with commitment and innovation. If they can do so successfully, it will be in their own interest and also in the interest of the planet. It is frequently argued that - in addition - it will be the right thing to do from a moral perspective. The use of "in addition" is significant: it illustrates one of the key 
conceptual challenges to understanding the (perceived) tension between the business case (corporations do things, including acting with integrity, because they will increase their profit) and the moral case (corporations do certain things because they are the right things to do, whether they will increase profit or not).

"In addition" implies that the business case and the moral case are viewed as separate, but that, if they were aligned, there would be no tension. At this stage, the reader's mind should be put at rest that this article is not about revisiting discussions on whether the business case/moral case debate should or should not be an "either/or" debate. It is argued that the traditional "and/and" resolution of this tension - that of enlightened self-interest - is both flawed and superficial. The resolution is flawed because it uses a theoretical sleight of hand to sidestep the choice between the two by arguing that corporations do things because they are the right things to do and that, fortunately for them, they also happen to be good for business, implying that the two dimensions are always related by happy coincidence. And the resolution is superficial because, more often than not, this approach is associated with mere lip service to fundamental ethical principles.

To set the context, the next section explores - briefly - different ways of viewing the world we live in and presents a concise historical background to CR. This is followed by a discussion of the contributions made by Porter and Kramer (2011) and Donaldson and Walsh (2015), an introduction to the UN Global Compact and a description and analysis of public disclosures made by South African signatories. The article concludes with suggestions on how Donaldson and Walsh's concept of optimised collective value (OCV) can contribute to improved corporate responsibility practices.

\subsection{Understanding the world in which people do business}

The following statements are oversimplified, but useful to understand the big picture. The way in which people view the world (and the role of business in the world) is framed by a theoretical approach (how to understand it), and a practical approach (how to change it). The theoretical approach may be either normative, prescribing what ought to be done, or it may be empirical, describing the way things are. Each of these views of the theoretical approach presents significant challenges and complexities. Practitioners often accuse those holding the normative view of being idealistic and not in touch with the business environment. The empirical approach is sometimes challenged because it does not grapple with the difficult ethical issues implicit in a business environment, and also because the large amounts of quantitative data associated with empirical investigation and the correlations between the data do not necessarily prove causation.

To summarise a lively debate that has ensued over many decades is not easy, but the following is an attempt to describe how - in broad terms - different individuals and corporations have viewed corporate responsibility over time. There has been progress from philanthropy and traditional CSR, to CSR based on enlightened self-interest or strategic CR, sometimes explained as a shift from focusing on how profits are spent, to how profits are made. 
Those who adopt traditional CSR approaches usually prefer a percentage of profits to be spent on worthy causes, often to offset the way in which the profits were made, and sometimes cynically refer to this spending as guilt money. Those who choose the enlightened self-interest approach take cognisance of both risks and opportunities, and are therefore strongly focused on stakeholder engagement. However, the latter approach is mostly opportunistic, and, if the business case is not strong enough, corporations might quickly lose interest and step away from what could be regarded as values-driven behaviour. Strategic CR is based on a deeper reflection on the purpose of business and the way in which corporations form an integral part of society. Driven by a clear understanding of the nature of the business, interventions are designed and contributions are made in such a way that the corporation uses its particular strengths to contribute to societal needs and thrive at the same time. Strategic CR is based on the real capabilities and specific expertise of the corporation and can achieve integration on two fronts. Firstly, so-called CSR activities are no longer peripheral, but are integrated into the core activities of the corporation. Secondly - and this is the most difficult part to achieve - the business case and moral case are not presented as part of an either/or choice, but rather there is a clear acknowledgement that core values are not negotiable. In other words, the moral case trumps the business case. This is also the preferred approach in this article.

Neither strategic CR nor stakeholder theory that forms the theoretical underpinning for the approach is new. As will be explained below, much of this thinking was incorporated, without recognition, in the creating shared value (CSV) model of Porter and Kramer (2011). It will be argued that CSV only emphasises the business case, while the contribution of Donaldson and Walsh (2015), namely optimised collective value (OCV), is built on a normative foundation without losing any of the strategic value implicit in CSV. It is acknowledged that terminology can be overwhelming or confusing, or both. In 2007 a complete reference guide with more than 350 definitions, entitled The $A$ to $Z$ of Corporate Social Responsibility was published (Visser, Matten, Pohl \& Tolhurst, 2007). Since then, CSV and OCV, as well as a few others, have been added to the list, and will be addressed in this article.

\subsection{The purpose of business}

Williams (2008:431) argues that there is an emerging new role for the corporation within society, and discusses the UN Global Compact as a useful forum where this role can be investigated. According to him, there is growing consensus that multinational corporations have a moral obligation as corporate citizens to assist the poor, but that the extent of these obligations is not clear. This is where the UN Global Compact offers a "forum under the umbrella of the United Nations" where this changing role of business and its moral purpose can be discussed (Williams, 2008:435). Although the choice to reference assisting the poor as an example might be more relevant from a philanthropic perspective, it is the acknowledgement of a moral obligation (the moral case) that is important here. 
Following a fairly scathing review of CSR by The Economist (2005), a follow-up report was published in 2008 by the same publication, where it refers to the fact that the 2005 report had "acknowledge[d], with regret, that the CSR movement had won the battle of ideas" (The Economist, 2008:4). Whether this regret had anything to do with Milton Friedman's views from 35 years earlier of CSR as unadulterated socialism is not clear, but the 2008 report - as indicated by its title of "Just Good Business" - acknowledges, with no regret this time, that "clearly CSR has arrived" (The Economist, 2008:4). It then proceeds to explain how companies should view this development (The Economist, 2008:14):

One way of looking at CSR is that it is part of what businesses need to do to keep up with (or, if possible, stay slightly ahead of) society's fast-changing expectations. It is an aspect of taking care of a company's reputation, managing its risks and gaining a competitive edge. This is what good managers ought to do anyway.

Those who support CR from a moral point of view increasingly support the "just good business" approach from an operational point of view. In other words, by integrating $\mathrm{CR}$ into the strategic elements of the corporation instead of having a marginalised CSR department with a separate budget, the positive impact on stakeholders can be increased. This raises the question of intentionality - does it count from a moral point of view if corporate behaviour is not based on a sense of moral duty? Immanuel Kant would say no, but many beneficiaries of CR will simply not care.

Although many scholars have questioned the originality of CSV with reference to stakeholder theory and strategic CR, it was pointed out by Malan (2016:103) that even the views of Milton Friedman contained many of the same ideas, as illustrated by Table 1.

Table 1: Comparison between the views of Porter and Kramer, and Friedman

\begin{tabular}{l|l}
\hline \multicolumn{1}{c|}{ Porter and Kramer } & \multicolumn{1}{c}{ Friedman } \\
\hline "It is not philanthropy but self-interested behavior to create & "It may well be in the long run \\
economic value by creating societal value. If all companies & interest of a corporation that is a \\
individually pursued shared value connected to their particular & major employer in a small community \\
businesses, society's overall interests would be served. & to devote resources to providing \\
And companies would acquire legitimacy in the eyes of the & amenities to that community or to \\
communities in which they operated." (2011:17) & improving its government." (2002:36) \\
\hline
\end{tabular}

Crane, Palazzo, Spence and Matten (2014) published a critique of CSV in which they described the approach as unoriginal and naïve, and as "a reactionary rather than transformational response to the crisis of capitalism" (Crane et al., 2014:131). Porter and Kramer responded defensively and re-asserted the novelty of their ideas (Porter \& Kramer, 2014), while labelling the views of Crane and colleagues as "wishful thinking" (Porter \& Kramer, 2014:150). In their final rejoinder, Crane et al. (2014:152) stated the following: "Where the wishful thinking really comes in though is in Porter and Kramer's naïve belief that the role of business in addressing the world's major social problems can, or should, only be addressed through the lens of corporate self-interest."

Malan (2016) has argued that corporations have to make decisions from time to time that will conflict with either their own perceived self-interest or those of their stakeholders. 
He also pointed to a perceived correlation between the moral case and philanthropy, and between the business case and strategic CR:

[T] here is a need to decouple the motivation for specific behaviour from the behaviour itself. It is becoming increasingly clear that the most effective way for corporations to respond to societal expectations is to integrate these activities into their day-to-day activities, and not to manage these as something separate or peripheral. But doing it in a particular way does not necessarily correlate with the motivation for doing it in the first place.

(Malan, 2016:105)

To explore the motivation for behaviour in more detail, we now turn to a different view of the purpose of business.

\subsection{Optimised collective value}

Although it was not published as a direct response to CSV, the contribution by Donaldson and Walsh (2015) on a theory of business presents a new perspective that could present a viable alternative. They argue that it is difficult to describe the purpose of business because we are confronted with a composition fallacy: a blurred double image of value, where "what counts as value for a single firm is laid atop an image of what counts as value for business in general" (Donaldson \& Walsh, 2015:181). Their goal is to develop a theory of business with both normative and empirical relevance, a goal that is reminiscent of Donaldson's earlier work with Dunfee on integrative social contracts theory (ISCT) (Donaldson \& Dunfee, 1999).

When they introduced ISCT formally, Donaldson and Dunfee (1994) positioned this theory as an attempt to bridge the gap between empirical and normative research in business ethics, where researchers with philosophical training mainly employ normative, non-empirical methods, while researchers in business and management science with training in empirical methods apply their techniques - mostly in descriptive fashion to areas such as managerial motivation and investigation of the relationship between ethical behaviour and financial performance. Donaldson and Dunfee (1994:254) describe their proposed theory as a "normative theory ... which incorporates empirical findings as part of the contractarian process of making normative judgments".

Donaldson and Walsh (2015:181) argue that there are three separate challenges when thinking about the nature of business: we grapple with the purpose of business, we struggle to deal with the composition fallacy, and we have to deal with the fact that business is not always an unalloyed good.

As was mentioned above, their contribution is not proposed as an alternative for CSV, but rather as a viable alternative to dominant neo-classical economics and in particular the theory of the firm. Donaldson and Walsh acknowledge that neo-classical economics serves business leaders well. However, they explain that the theory was not developed to address society's broader interest in business activity. In other words, the theory functions well for its designated purpose, but the problem is that the purpose itself is limited. 
In response, Donaldson and Walsh (2015:182) outline the beginning of a theory of business, which has to focus on four aspects: purpose, accountability, control and the nature of business success. The following three definitions are important to understand their argument (Donaldson \& Walsh, 2015:188):

- Positive value: a reason for acting where the object of the act is seen as worthy of pursuit;

- Intrinsic value: a positive value whose worth does not depend on its availability to achieve other positive value (dignity being the key intrinsic value); and

- Collective value: the agglomeration of the business participants' benefits, net of any aversive business outcomes.

Ultimately, Donaldson and Walsh describe business success as optimised collective value (OCV). This is a normative description, because it says something about the world we hope to inhabit. As humans, we need to determine what is acceptable and unacceptable in terms of approaching that world, and the intrinsic value of dignity establishes that minimum decision criterion. Each individual firm holds two interrelated purposes - a focal purpose and a contextual purpose. The focal purpose is to provide a high-quality good or service at a competitive, profit-making price. If this is not achieved, the firm will go out of business. The contextual purpose is described as follows (Donaldson \& Walsh, 2015:198):

[a] firm is a human creation, one designed by humans and for humans. At a minimum, all of its activities must clear the Dignity Threshold. No firm should disrespect the inherent worth, the dignity, of its many Business Participants. It must treat each one with respect. Moreover, no firm should forget that the final justification of its activities from a social perspective lies in its contribution to collective value.

One of the most innovative contributions of Donaldson and Walsh (2015) is the introduction of the blurred double image of value (the composition fallacy of value for the single firm and value for business in general). But there is also another blurred image of value: economic value and moral value.

The origin of value and values can be found in old French (valoir) and Latin (valere), both referring to the intrinsic worth of something, and historically value was only sometimes expressed as a quantified amount equivalent to its worth. Porter and Kramer (2011) clearly have a preference for economic value, and also focus on the value for the single firm. On the other hand, Donaldson and Walsh (2015) emphasise the normative dimension of their approach, while at the same time focusing on the creation of value for business in general, which means they are diametrically opposed to the philosophy that underpins CSV. 


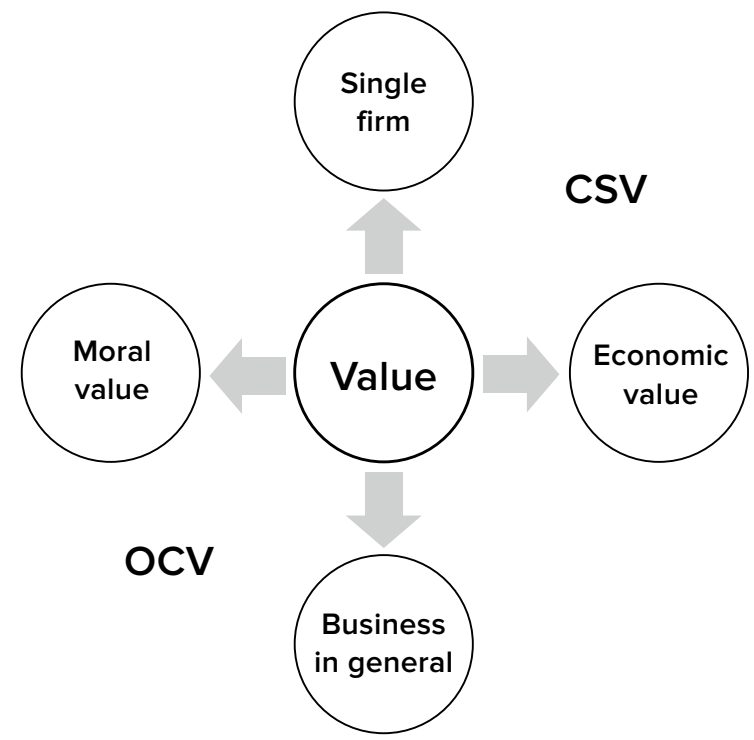

Figure 1: Plotting creating shared value (CSV) and optimised collective value (OCV)

It would be too crude to place Porter and Kramer (2011) and Donaldson and Walsh (2015) squarely in opposing camps by arguing that they support either the business case or the moral case. But it is clear that Porter and Kramer have a strong preference for the business case, and that the position of Donaldson and Walsh is the only one of the two that has a normative foundation. The next section will introduce the UN Global Compact and then explore how corporations reflect their preferences implicitly when they report on CR.

\subsection{The United Nations Global Compact}

In 1999, Kofi Annan, then secretary-general of the United Nations, introduced the concept of a global compact to multinational corporations gathered at the annual meeting of the World Economic Forum in Davos, Switzerland. He described the fragility of globalisation as follows (United Nations, 1999):

The spread of markets outpaces the ability of societies and their political systems to adjust to them, let alone to guide the course they take. History teaches us that such an imbalance between the economic, social and political realms can never be sustained for very long.

The response from the business sector was so encouraging that the concept was formalised approximately 18 months later, when the Global Compact was launched on 26 July 2000 at the UN Headquarters in New York. ${ }^{2}$ The launch took place a mere seven months after the infamous 'Battle for Seattle', where violent anti-globalisation protests broke out at the ministerial Conference of the World Trade Organisation. Against a backdrop of frequently strained relations, the launch of the Global Compact signalled a "new era of cooperation" between the business community and the UN (Rasche \& Kell, 
2010:3). According to Rasche and Kell (2010:3), the Global Compact was "the creative answer to the many unaddressed governance gaps which deteriorated as a result of the worldwide expansion of value and supply chains”.

A strategy note from the United Nations, drawn up by former executive director of the UN Global Compact Georg Kell (2013) in preparation for the Davos speech of Annan, acknowledges that UN values and principles in the areas of labour standards, human rights and environmental principles have become important points of reference for individual corporations and global debates. The note proposes "that the Secretary General challenge the international business community to support, advocate and implement a framework of universal standards for business to use as benchmarks against which their internal codes of conduct and behaviour can be judged" (United Nations, 1998:2). The note identified a number of potential gains from the initiative. These included the incorporation of UN reference points into corporate mission statements and operations; the strengthening of the secretary-general's leadership role in the evolving issue of UN relations with business; and the development of a broader case for balancing global governance in favour of developmental, social and environmental concerns (United Nations, 1998:3).

The UN summed up its potential target market in a brutally honest way at this early stage, and the organisation should be commended for placing this information in the public domain. The note identified four types of corporations that were likely to support the initiative (some corporations are mentioned by name): the types are referred to as soft targets; free riders; corporations that would like to expand markets or reduce risk; and, finally, consulting organisations. ${ }^{3}$

Today, the UN Global Compact is the world's largest voluntary corporate citizenship initiative with approximately 9000 business and 3000 non-business signatories. It used to describe itself as "a strategic policy initiative for businesses that are committed to aligning their operations and strategies with ten universally accepted principles in the areas of human rights, labour, environment and anti-corruption", ${ }^{4}$ but more recently it has used a description more closely aligned with the Sustainable Development Goals (SDGs): "We are a voluntary initiative based on CEO commitments to implement universal sustainability principles and to take steps to support UN goals". ${ }^{5}$

The 10 principles were derived from the Universal Declaration of Human Rights, the International Labour Organization's Declaration on Fundamental Principles and Rights at Work, the Rio Declaration on Environment and Development, and the United Nations Convention against Corruption.

The 10 UN Global Compact principles are displayed in Table 2. 
Table 2: The United Nations Global Compact principles

\begin{tabular}{|c|c|c|}
\hline Area & & Principles \\
\hline \multirow{2}{*}{ Human rights } & 1. & $\begin{array}{l}\text { Businesses should support and respect the protection of internationally } \\
\text { proclaimed human rights. }\end{array}$ \\
\hline & 2. & $\begin{array}{l}\text { Businesses should make sure that they are not complicit in human } \\
\text { rights abuses. }\end{array}$ \\
\hline \multirow{4}{*}{ Labour standards } & 3. & $\begin{array}{l}\text { Businesses should uphold the freedom of association and the effective } \\
\text { recognition of the right to collective bargaining. }\end{array}$ \\
\hline & 4. & $\begin{array}{l}\text { Businesses should support the elimination of all forms of forced and } \\
\text { compulsory labour. }\end{array}$ \\
\hline & 5. & Businesses should support the effective abolition of child labour. \\
\hline & 6. & $\begin{array}{l}\text { Businesses should support the elimination of discrimination in respect } \\
\text { of employment and occupation. }\end{array}$ \\
\hline \multirow{3}{*}{ Environmental standards } & 7. & $\begin{array}{l}\text { Businesses should support a precautionary approach to environmental } \\
\text { challenges. }\end{array}$ \\
\hline & 8. & $\begin{array}{l}\text { Businesses should undertake initiatives to promote greater } \\
\text { environmental responsibility. }\end{array}$ \\
\hline & 9. & $\begin{array}{l}\text { Businesses should encourage the development and diffusion } \\
\text { of environmentally friendly technologies. }\end{array}$ \\
\hline Anti-corruption & 10. & $\begin{array}{l}\text { Businesses should work against corruption in all its forms, including } \\
\text { extortion and bribery. }\end{array}$ \\
\hline
\end{tabular}

Companies that join the UN Global Compact are expected to fulfil certain requirements. ${ }^{6}$ The communication on progress (COP) is one of the most important tools for signatories to report on how they have supported the 10 principles. The UN Global Compact rule requires new participants to submit their first $\mathrm{COP}$ one year after joining the initiative, and thereafter on an annual basis. ${ }^{7}$ The way in which the COP system is administered - specifically with regard to the threat of expulsion for non-submission - has created the impression among some stakeholders that the UN Global Compact is a compliancebased system. Although the COP system is there to provide some consistency and accountability, the UN Global Compact as a whole should not be viewed as a compliancebased initiative. In the words of Kell: ${ }^{8}$

The Compact never pretended to [be a compliance-based institution], nor was it designed as one. The fact that some observers continue to criticize the Compact for something it never pretended to be is remarkable. Ever since the inaugural launch on 26 July 2000, we have been very clear that the Compact is about learning, dialogue and partnerships. The UN does not endorse companies or their performance. Rather, it seeks to promote collaborative efforts, transparency and public accountability.

The COP remains a subjective account, even if verified externally, but does provide useful insight into activities of UN Global Compact signatories, and is probably the most important way in which external stakeholders can assess the performance of a participating corporation. It also provides a useful glimpse into corporate views on $\mathrm{CR}$ and underlying, implicit philosophies. This will be explored in the next section. 
This section examines the extent to which South African corporations that are active participants in the UN Global Compact emphasise either the business case or the moral case when implementing, and communicating on, the 10 principles of the UN Global Compact. In order to do this, the COPs of all active South African corporations were assessed. ${ }^{9}$ The corporations that were included in the analysis were: Altron, AngloGold Ashanti, Barloworld, Coca-Cola Sabco, Deloitte, Edcon, Eskom, Exxaro, FirstRand, Gold Fields, Impala Platinum, Mondi, Nedbank, Pick n Pay, Richards Bay Coal Terminal, Sanlam, Sappi, Sasol and Unilever. These 19 corporations represent the total population of South African corporations that were active in the UN Global Compact at the time of writing. ${ }^{10}$

The purpose of the exercise was to analyse the level of public reporting. There were some instances where companies either provided a Global Reporting Initiative (GRI) table or links to external websites in their COP submission, referencing sources not uploaded on the UN Global Compact website. In these cases, the external sources were also included in the assessment.

As expected, it was a difficult task to measure the qualitative value of certain statements. Companies tended to have markedly different strategies for addressing the different areas. For environment, many companies had a business-centred strategy, given that improvements in energy efficiency have financial benefits. For human rights, such as the prohibition of child labour, it was more likely that companies would approach these issues from a moral perspective.

In general, corporations tended to focus on universal values and commitments with less emphasis on local flexibility. Companies did, however, place great emphasis on compliance with local legislation. This was understandable in the South African context where there are specific commitments to labour laws and black economic empowerment obligations. Hamann, Agbazue, Kapelus and Hein (2005) discuss the challenges that are specific to South Africa with regard to universal corporate governance standards. They mention the historical legacy of poverty and inequality, distrust of corporations, and accusations of 'greenwashing', the existence of home-grown and disparate conceptions of CSR, the role of the state, and specific issues related to small and medium enterprises as some of the South African peculiarities and complexities that demonstrate how difficult it is for a global standard to add value at the local level (Hamann et al., 2005:3). Although their discussion is aimed specifically at the International Organization for Standardization (ISO), it can also be applied to concerns about the UN Global Compact (Hamann et al., 2005:16):

There is the danger that [a global] standard will contribute to an emphasis on a formalized set of universal norms and practices that represent the lowest common denominator in the international debate. The true test for the standard will not only be its ability and flexibility in allowing for the innovation, creativity, and responsiveness necessary to meet national or local challenges and priorities, but to actively encourage such context-specific approaches to CSR. 


\section{Description of study population}

The 19 active South African corporations that formed part of this investigation have been involved with the UN Global Compact for a substantial amount of time. Almost 80 per cent of the South African signatories have been participants for more than five years, while the rest have all been signatories for between one and five years. Detailed information on all signatories, including the date of joining, level of participation and nature of communication can be found at www.unglobalcompact.org.

The UN Global Compact makes a distinction between three different levels: learner, active and advanced. The differentiation programme ${ }^{11}$ is based on a self-assessment in terms of the levels of disclosure as well as the implementation of the 10 principles. Sixty-eight per cent of the South African corporations indicated that they were at the active level. The active level is reserved for participants that fulfil all the minimum COP requirements, including addressing all four areas under investigation and communicating directly with stakeholders. $^{12}$

Twenty-one per cent of the assessed corporations indicated that they were at the advanced level, which is reserved for corporations that strive to be top performers. These corporations declared that they had adopted, and reported on, best practices in sustainability governance and management, with specific reference to some of the UN Global Compact initiatives, such as the Blueprint for Corporate Sustainability Leadership and the UN Global Compact Management Model. The corporations which indicated that they had reached this level were Unilever, Sasol, Mondi and Eskom. In terms of organisation type, publicly listed companies dominated the South African sample (63 per cent), followed by private companies (26 per cent), one subsidiary (Unilever) and one state-owned company (Eskom). Large corporations dominated the sample, with 74 per cent having more than 10000 employees, and 63 per cent having had a turnover of more than $\$ 5$ billion in the last financial year.

\section{Methodology and results}

The methodology of narrative analysis was applied. The COPs were assessed on the basis of their emphasis on either the business case or the moral case; on either the global or the local context; and either performance or conformance aspects of governance. Finally, a general assessment was made of whether the COPs were mainly a public relations exercise; mainly a compliance exercise; or whether a clear commitment to the principles of the UN Global Compact was demonstrated.

The assessment was done on the basis of an analysis of both the CEO statement and the COP itself. In all cases a four-point Likert scale was applied. Table 3 illustrates that the vast majority of companies used the business case to motivate their support for corporate responsibility. The one exception to this was Exxaro, which placed a very strong emphasis on the moral case. Exxaro explained its support for the UN Global Compact 
as a "logical progression in our ongoing commitment to sustainability, given our shared goals and focus on universal values". ${ }^{13}$ The corporations that focused most strongly on the business case were Altron, Eskom, FirstRand and Sappi.

Table 3: Corporate preference for business case or moral case in terms of corporate responsibility

\begin{tabular}{l|c}
\hline \multicolumn{1}{c|}{ Category } & Percentage of companies \\
\hline Very strong business case & 21 \\
\hline Emphasis on business case & 74 \\
\hline Emphasis on moral case & 0 \\
\hline Very strong moral case & 5 \\
\hline
\end{tabular}

The acknowledgement of global and local complexities was assessed, and the results are displayed in Table 4.

Table 4: Emphasis on global or local context

\begin{tabular}{l|c}
\hline \multicolumn{1}{c|}{ Category } & Percentage of companies \\
\hline $\begin{array}{l}\text { Very strong emphasis on global/universal values; little or no room for } \\
\text { local flexibility }\end{array}$ & 0 \\
\hline $\begin{array}{l}\text { Strong emphasis on global/universal values; clear acknowledgement } \\
\text { of need for local flexibility }\end{array}$ & 38 \\
\hline $\begin{array}{l}\text { Strong emphasis on need for local flexibility; clear acknowledgement } \\
\text { of global/universal values }\end{array}$ & 32 \\
\hline $\begin{array}{l}\text { Very strong emphasis on need for local flexibility; little or no } \\
\text { acknowledgement of global/universal values }\end{array}$ & 0 \\
\hline
\end{tabular}

The governance focus of the COPs was analysed to assess the relative importance attached to the two main components of governance as explained in the classical definition of governance: the system by which corporations are directed (performance) and controlled (conformance). Globally there has been a shift from conformance to performance, with the United States still a notable exception owing to its strong culture of legal regulation. With the inclusive, stakeholder-based approach of the South African King Reports, which also emphasise a balanced approach to governance, it was expected that performance would be the main emphasis. The results are displayed in Table 5.

Table 5: Analysis of governance focus

\begin{tabular}{l|c}
\hline \multicolumn{1}{c|c}{ Category } & Percentage of companies \\
\hline Exclusive focus on performance & 21 \\
\hline Emphasis on performance & 53 \\
\hline Emphasis on conformance & 26 \\
\hline Exclusive focus on conformance & 0 \\
\hline
\end{tabular}

Finally, an overall assessment of the COPs was performed and the results are displayed in Table 6. Eskom was the only corporation that attained a best practice assessment. 
Table 6: Overall assessment of COP

\begin{tabular}{l|c}
\hline \multicolumn{1}{c|}{ Category } & Percentage of companies \\
\hline Mainly public relations & 21 \\
\hline Mainly UN Global Compact compliance & 74 \\
\hline Clear commitment to UN Global Compact & 0 \\
\hline Clear commitment to UN Global Compact, example of best practice & 5 \\
\hline
\end{tabular}

It is significant to note the good performance of Eskom, one of South Africa's most controversial corporations. As the national electricity utility, the corporation has been under scrutiny for underperformance over the past few years. The fact that Eskom's electricity generation is still largely dependent on high-polluting coal power stations does not improve its image from an environmental perspective. The reason for Eskom's good performance in this assessment can therefore be found either in the positive view that the corporation made honest disclosures and a sincere attempt to improve performance, or in the cynical view that the corporation may be guilty of blue washing.

The critical question is: To what extent were the disclosures that were made accurate and made in good faith? In his introduction to the COP, then CEO of Eskom Brian Dames states: "We are confident that we are setting the utility up for success; that our organisation is becoming financially sustainable" (Eskom, 2012:2). In the same document, the chairman of Eskom, Zola Tsotsi, states: "At a time when global economic uncertainty is forcing many companies to curtail operations and limit growth, Eskom is hard at work on one of the largest capital expansion programmes in South Africa's history" (Eskom, 2012:1). Yet, barely a year later Eskom had to accept a R250 billion bailout package from the South African government, ${ }^{14}$ the CEO resigned (for "personal reasons" ${ }^{15}$ ), the promised capital expansion was far behind schedule, and the pressure on the national electricity grid was such that frequent countrywide rolling blackouts were required. More recently, Eskom was also implicated in a report on state capture issued by the South African Public Protector. The purpose here is not to provide a detailed case study of Eskom. It is also not the intention to assess whether the corporation deserves its top position in terms of this assessment, or whether the advanced status according to the UN Global Compact differentiation programme is justified. However, it does underscore the fact that publicly available reports remain just that - publicly available reports.

\section{Conclusion}

The purpose of business is and will remain a matter of dispute. Debates will continue within both academic and practitioner environments, and in the long term will be influenced more by a systemic focus than an organisational behaviour focus. Preferences for a normative approach can be articulated convincingly and consistently, but cannot be grounded empirically. There is no empirical proof that a normative approach is better.

It is too early to gauge the impact that the development of a theory of business will have on this debate. The one advantage that is offered by the early research offerings, which 
is also present in integrative social contracts theory, is that the proposed theory has both normative and empirical relevance (Donaldson \& Walsh, 2015:182).

The main empirical findings presented in this article are that almost all South African signatories to the United Nations Global Compact emphasised the business case in their communications on progress (COPs) and that the majority of corporations also focused on the global picture rather than on local complexities. Although not part of the research performed here, it would be fair to state that it is very likely that the majority of these corporations (if not all of them) will be familiar with creating shared value (CSV), but not with optimised collective value (OCV), and - if given an immediate choice - would prefer the first to the second.

The empirical findings discussed here are illuminating and somewhat disillusioning and - if subsequent research proves these preferences to be present at the global level as well, which is very likely - it will indicate an uphill battle ahead for those who argue in favour of a normative approach. Such an indication will be no surprise, but the conceptual framework provided by the proposed theory of business could make this battle slightly easier.

\section{Ethical approval}

This article does not contain any studies with human participants or animals performed by any of the authors.

\section{References}

Carroll, A., Lipartito, K., Post, J., Werhane, P. \& Goodpaster, K. (2012). Corporate responsibility: The American experience. Cambridge: Cambridge University Press. https://doi.org/10.1017/CBO9781139108041

Crane, A., Palazzo, G., Spence, L.J. \& Matten, D. (2014). Contesting the value of "Creating Shared Value". California Management Review, 56(2):130-153. https://doi.org/10.1525/cmr.2014.56.2.130

Donaldson, T. \& Dunfee, T. (1994). Toward a unified conception of business ethics: Integrative Social Contracts Theory. Academy of Management Review, 19(2):252-284. https://doi.org/10.2307/258705

Donaldson, T. \& Dunfee, T. (1999). Ties that bind: A social contracts approach to business ethics. Boston: Harvard University Press.

Donaldson, T. \& Walsh, J. (2015). Toward a theory of business. Research in Organizational Behavior, 35:181-207. https://doi.org/10.1016/j.riob.2015.10.002

Eskom. (2012). Advanced Communication on Progress 2012. Eskom, Johannesburg.

Friedman, M. (2002). The social responsibility of business is to increase its profits. In:T. Donaldson, P. Werhane \& M. Cording (eds.), Ethical issues in business: A philosophical approach. Seventh edition. New Jersey: Prentice Hall. 33-38.

Hamann, R., Agbazue, T., Kapelus, P. \& Hein, A. (2005). Universalizing corporate social responsibility? South African challenges to the International Organization for Standardization's new social responsibility standard. Business and Society Review, 110(1):1-19. https://doi.org/10.1111/j.0045-3609.2005.00001.x

Kell, G. (2013). Former Executive Director of the UN Global Compact. New York: Personal interview, 5 August.

Malan, D. (2016). Corporate support for the SDGs: A South African perspective. The Journal of Corporate Citizenship, 64(December):98-21. https://doi.org/10.9774/GLEAF.4700.2016.de.00011 
Porter, M. \& Kramer, M. (2011). Creating shared value. Harvard Business Review (HBR Reprint R1101C):1-17.

Porter, M. \& Kramer, M. (2014). A response to Andrew Crane et al's article by Michael E. Porter and Mark R. Kramer. California Business Review, 56(2):149-151.

Rasche, A. \& Kell, G. (2010). The United Nations Global Compact: Achievements, trends and challenges. New York: Cambridge University Press. https://doi.org/10.1017/CBO9780511762642

Smith, N. \& Lenssen, G. (eds.) (2009). Mainstreaming Corporate Responsibility. Chichester: John Wiley \& Sons.

The Economist. (2005). The good company: A survey of corporate social responsibility, 22 January.

The Economist. (2008). Just good business: A special report on corporate social responsibility, 19 January.

United Nations. (1998). Linking universal values with the global reach of business - Strategy note for Davos speech (summary). https://www.unglobalcompact.org/docs/about_the_gc/GC_Strategy_note_18Dec98. pdf [Accessed 14 December 2014].

United Nations. (1999). Secretary-general proposes Global Compact on human rights, labour, environment, in address to World Economic Forum in Davos. http://www.un.org/News/Press/docs/1999/19990201. sgsm6881.html [Accessed 12 February 2017].

Visser, W., Matten, D., Pohl, M. \& Tolhurst, N. (2007). The A to Z of Corporate Social Responsibility. Chichester: John Wiley \& Sons.

Williams, O.F. (2008). Responsible corporate citizenship and the ideals of the United Nations Global Compact. In: O. Williams (ed.). Peace through commerce: Responsible corporate citizenship and the ideals of the United Nations Global Compact. Notre Dame: Notre Dame University Press. 431-552. 


\section{Endnotes}

1. http://us7.campaign-archive1.com/?u=95a3a559c205fcb6178629d7e\&id=aa0a3091fb\&e=8e 6c207732, accessed 9 November 2016.

2. The Global Compact became the United Nations Global Compact in 2007, when the UN officially allowed its name to be attached to the initiative.

3. The different types are described as follows (United Nations, 1998:11-12): soft target corporations are those forced to confront social responsibility in response to encounters with lobby groups (Shell, BP, Rio Tinto, Nike, McDonalds and Reebok are used as examples); free riders are corporations that see general image gain by associating themselves with UN values/ principles without necessarily having to confront the issues (Nokia and BMW are used as examples); corporations that can gain from specific UN activities in order to expand markets or reduce risks (ABB is the only example mentioned here); and consulting corporations (the 'big five' accounting firms are used as examples). These corporations are described as "enthusiastic supporters of almost all forms of social responsibility as this creates a new market for auditing".

4. http://www.unglobalcompact.org/AboutTheGC/index.html, accessed 7 February 2018.

5. https://www.unglobalcompact.org/about, accessed 15 March 2016.

6. These are:" $[\mathrm{m}]$ ake the Global Compact and its principles an integral part of business strategy, day-to-day operations and organisational culture; [i]ncorporate the Global Compact and its principles in the decision-making processes of the highest-level governance body (i.e. Board); [c]ontribute to broad development objectives (including the Millennium Development Goals) through partnerships; [i]ntegrate in the annual report (or in a similar public document, such as a sustainability report) a description of the ways in which the company implements the principles and supports broader development objectives (also known as the communication on progress or COP); and [a]dvance the Global Compact and the case for responsible business practices through advocacy and active outreach to peers, partners, clients, consumers and the public at large" (https://www.unglobalcompact.org/HowToParticipate/Business_ Participation/index.html, accessed 18 December 2014).

7. https://www.unglobalcompact.org/COP/cop_deadlines.html, accessed 23 November 2014. Previously, signatories were given two years to submit their first COP.

8. http://www.ethicalcorp.com/content.asp?ContentID=5898\&newsletter=24, accessed 13 May 2008.

9. The valuable contribution of a research assistant, Roan Snyman, is acknowledged.

10. Although the name of the Public Investment Corporation also appeared on the list of active signatories at the time, there was only a placeholder COP available and therefore it was excluded from the analysis.

11. https://www.unglobalcompact.org/COP/differentiation_programme.html, accessed 25 November 2014.

12. https://www.unglobalcompact.org/COP/differentiation_programme.html, accessed 25 November 2014.

13. Exxaro 2012 COP, p. 1.

14. http://mg.co.za/article/2014-09-15-government-to-bail-out-eskom, accessed 7 February 2018. 
15. In an interview with a Sunday newspaper, Eskom CEO Dames said the following: "I just want to have a rest ... (The job) takes a lot out of you. Really it never ends. I normally say to people that I just want a life." http://www.iol.co.za/business/companies/i-just-need-a-rest-ex-eskomceo-1.1618740\#.VHulEM8cSpo, accessed 7 February 2018. 